\title{
RADOŚĆ ZAPISANYCH W NIEBIE. LK 10, 20 W INTERPRETACJI PATRYSTYCZNEJ
}

Powracających z pierwszej wyprawy misyjnej i zadowolonych ze swoich dokonań siedemdziesięciu dwóch uczniów Jezus pragnie wychować do dojrzałej radości: „Jednakże nie z tego się cieszcie, że duchy się wam poddają lecz cieszcie się, że wasze imiona zapisane są w niebie" (Łk 10, 20). Łukasz jako jedyny relacjonuje dwa rozesłania misyjne: najpierw Apostołów, a potem uczniów. I tylko on zamieszcza powyższy dialog Jezusa z uczniami. Na podstawie formalnych odniesień Ojców łacińskich i greckich do powyższej wypowiedzi przedstawimy patrystyczną interpretację tych słów.

\section{ZNAKI ZEWNĘTRZNE A POSTAWA WEWNĘTRZNA}

Wielu autorów idzie za użytą przez Jezusa przeciwstawnością pomiędzy nadzwyczajnym czynem wypędzania złych duchów a tym, co czyni ich rzeczywiście godnymi zapisu w niebie. Chrystus nie wskazał na to, co czyni Jego współpracowników godnymi tego uwiecznienia, a jedynie na sam fakt uwiecznienia i radość z tego powodu. Jakby niedokończona wypowiedź Jezusa prowokowała komentatorów do pewnych dopowiedzeń. Ojcowie rozciągają ów kontrast na kilka rzeczy. Tak oto przeciwstawiają czynienie cudów osobistej postawie cudotwórcy przejawiającej się w jego wierze, miłości oraz sprawiedliwych uczynkach.

1. Wiara nadaje uczynkom trwałość. Ambroży wskazuje, że zapis w niebie imion uczniów Chrystusa jest Jego łaską oraz zasługą ich wiary i pobożności․ Nie zostają uwiecznieni przez cuda czynione łaską Bożą, ale przez swoją wiarę. Jan Chryzostom ilustruje powyższą prawdę przykładem Piotra Apostoła. Obietnica zapisania w niebie spełniła się w ten sposób, że został nazwany przez Chrystusa nowym imieniem - Opoka. Nadane przez Chrystusa znamię

* Dr hab. Leon Nieścior OMI, prof. UKSW - kierownik Katedry Teologii Patrystycznej w Instytucie Teologii Sytstematycznej na Wydziale Teologicznym Uniwersytetu Kard. Stefana Wyszyńskiegow Warszawie; e-mail: 1.niescior@uksw.edu.pl.

${ }^{1}$ Por. Ambrosius, Hexaemeron I 6, 21, ed. C. Schenkl, CSEL 32/1, Vindobonae 1897, 17, thum. W. Szołdrski: Św. Ambroży, Hexaemeron, PSP 4, Warszawa 1969, 44-45. 
trwałości znalazło wyraz nie tylko w roli, jaką Piotr odegrał, ale nawet w samym imieniu. Tego trwałego i zapisanego w niebie imienia nie otrzymał dzięki czynionym cudom, ale dzięki żarliwej wierze, która wyraziła się w wyznaniu prawdy o Chrystusie, Synu Bożym (Mt 16, 16-18)2. Beda Czcigodny nie używa w interesującym nas kontekście słowa „wiara”, ale zdaje się na nią wskazywać. Jego zdaniem racją, dla której wypędzanie złych duchów i czynienie innych cudów nie powinno zbyt cieszyć uczniów, jest przede wszystkim ten fakt, że ostatecznie to nie oni są ich sprawcami, ale Chrystus. Czynią je w Jego imię. Znaki te nie dokonują się na skutek ich zasług, ale na wezwanie imienia Chrystusowego. Mają prowadzić do chwały Boga, a nie chwały działających w Jego imię. Samo wypędzanie złych duchów nie dowodzi zasług tych, którzy je wypędzają. Taką moc mieli synowie Skewasa, arcykapłana żydowskiego, udzielający egzorcyzmów w imię Jezusa (Dz 19, 13n.), czy Judasz ${ }^{3}$.

2. Chrystus powołal sprawiedliwego Szymona. W innym miejscu Beda Czcigodny zajmuje się symboliką innego imienia Księcia Apostołów. W nazwaniu przez Jezusa tego Apostoła jego macierzystym imieniem - „Szymon, syn Jony" (Mt 16, 17) - dostrzega aluzję do naturalnej szlachetności i sprawiedliwości Piotra. W jakiś sposób stoi ona u podstaw wybrania go przez Mistrza. Na ogół nie ma nic szczególnego w tym, aby nazwać kogoś jego własnym imieniem czy imieniem ojca. Tym bardziej, że Bóg zachowuje imiona swoich świętych w niebie, a Piotr jest jednym ze świętych. W tym wypadku nazwanie nosi jednak charakter symbolu. Zanim nadał Apostołowi imię o wyższej randze, czyniąc go zwierzchnikiem całego Kościoła, chciał najpierw pokazać, że i imię otrzymane od rodziców było wyrazem jego prawości. Ponieważ „Szymon” oznacza „posłuszny”, a „Jona” oznacza „łaskę Bożą̧, więc Jezus nazywając Szymona „synem Jony” zobaczył w nim syna posłusznego łasce Bożej ${ }^{4}$. Zanim Jezus powołał Piotra do wyjątkowej misji, odwołał się do pewnych moralnych zasług Szymona, do wcześniej okazywanej przez niego postawy względem Boga. Jeśli Bóg zapisuje imiona świętych w niebie, to podobnie Jezus za ziemskiego życia dostrzegał i respektował osobistą drogę życia każdego, kogo powołał.

3. Liczy się końcowa sprawiedliwość. Ambrozjaster zastanawia się nad trwałością owego zapisu w niebie dzięki usprawiedliwieniu przez wiarę. Jego zdaniem, jeśli nawet Chrystus obiecuje, że imiona ich będą zapisane w nie-

${ }^{2}$ Por. Joannes Chrysostomus, In principium Actorum hom. 2, 6, PG 51, 65-112.

${ }^{3}$ Por. Beda Venerabilis, In Lucae evangelium expositio III 10, 20, ed. D. Hurst, CCL 120, Turnholti 1955, 219.

${ }^{4}$ Por. tenże, Homiliarum evangelii lib. 1, 16, ed. D. Hurst, CCL 122, Turnholti 1960, 115. Współczesne leksykony podają podobny sens tych imion: „Szymon” oznacza „słuchacza”, „słuchającego”, „Jona” (Jan, Jonah, Johanan, Jonasz) - „dar od Boga”, por. np. F. Rienecker - G. Maier, Leksykon biblijny, thum. D. Irmińska, Warszawa 2001, 788. 
bie, to nie w sposób nieodwołalny. Chociaż Chrystus wybrał Siedemdziesięciu Dwóch, i to w jakimś drugim porządku, po Apostołach, to jednak wiedział, że część z nich odstąpi od niego. Zostali wybrani wedle aktualnej swojej sprawiedliwości, bo byli dobrymi ludźmi. Godzi się, aby Bóg wybierał uwzględniając zasługę człowieka (pro merito). Zostali wybrani do posługi i ich imiona zostały zapisane w niebie ze względu na ich sprawiedliwość. Jednak Chrystus wiedział dzięki uprzedniej wiedzy, jak odpowiedzą na swoje powołanie, i na podstawie tej wiedzy niektórzy z nich zostali w końcu zaliczeni do grona złych ludzi ${ }^{5}$. Ostateczny wybór Boży dokonuje się na podstawie ostatecznego wyboru człowieka.

4. Wiara wymaga milości. Sama wiara przenosząca góry (1Kor 13, 2), nawet trwała, podobnie jak moc czynienia cudów, nie kwalifikuje do Królestwa Bożego. W sporze z donatystami Augustyn przypomina o potrzebie miłości i jedności. Zarówno katolicy, jak i donatyści, mogą czynić cuda, jednak są one bezwartościowe, jeśli nie mają odniesienia do wspólnoty. Wielu nie czyni cudów, a posiądzie królestwo Boże, tymczasem wielu czyni je, a nie posiądzie go. Chrystus przestrzega w Łk 10, 20 przed upatrywaniem podstawy swego zbawienia w samym czynie wiary. Wiara wymaga koniecznie miłości ${ }^{6}$. Podobnie Chryzostom stwierdza, że nie wystarcza samo wypędzanie złych duchów, aby wejść do królestwa Boga. Tym, co rozstrzygające, jest miłość. Mówiąc o wymogu miłości, wiąże Łk 10, 20 z obrazem sądu ostatecznego w Mt 7, 22. Nie należy zresztą przeciwstawiać cudów i miłości. Apostołowie wielu pociągali do wiary przez cuda dlatego, że wynikały one z miłości. „Gdyby nie było miłości, nie byłoby i cudów" ". W tym świetle miłość jawi się jako racja, która sprawia, że nasze imiona „zapisane są w niebie”.

5. Ważniejsza jedność niż cuda. Wyższość miłości od cudotwórstwa Augustyn uzasadnia, odwołując się do tajemnicy Kościoła jako Mistycznego Ciała Chrystusa. Gdy Apostołowie wrócili „,po głoszeniu wiary narodom”, Chrystus w Łk 10, 17 odwraca ich uwagę od samych siebie i zachęca do myślenia w kategoriach wspólnoty: „bo poza jednością i ten, który czyni cuda, jest niczym". Ważniejsza jest jedność niż cuda. W jedności bowiem pozostawał lud Izraela i cudów nie działał. Poza jednością byli czarnoksiężnicy faraona i czynili znaki podobne do Mojżeszowych (Wj 7, 12). I ci, którzy czynią cuda, i ci, którzy ich nie czynią, należą do jednego Kościoła. Augustyn wykłada tę prawdę po kaznodziejsku:

\footnotetext{
${ }^{5}$ Por. Ambrosiaster, Commentarius in Pauli epistulas. Ad Romanos (recensio gamma) 9, 13, ed. H.I. Vogels, CSEL 81/1, Vindobonae 1966, 315.

${ }^{6}$ Por. Augustinus, Contra litteras Petiliani II 55, 126, ed. M. Petschenig, CSEL 52/2, Vindobonae 1909, 91.

${ }^{7}$ Joannes Chrysostomus, In Joannem hom. 72, 4, PG 59, 394, tłum. własne.
} 
„Nie wiem, czy jakaś staruszka wdowa, nie wiem, czy jakiś świecki człowiek, mający miłość i silną wiarę, nie mógł tego [tj. cudów] czynić. Piotr w ciele Kościoła jest okiem, ów zaś tylko palcem, a jednak jest w tymże ciele, w którym jest Piotr"».

Wszyscy ci są jakoś zapisani do jednej księgi. Na innym miejscu, wskazując na pierwszeństwo jedności przed różnymi charyzmatami, Augustyn podkreśla autonomiczną wolę Boga, który jest dawcą darów. Chrystus nie wszystkich obdarzył darem wskrzeszania umarłych, uzdrawiania ślepych, głuchych czy trędowatych. Dary te dał tym, którym chciał dać. Zresztą, takie umiejętności niektórzy ludzie otrzymali jeszcze przed Wcieleniem. Czynił to ten sam Chrystus, istniejący przed Abrahamem jako Bóg, a po Dawidzie - również jako człowiek. Dokonywał tego za pośrednictwem innych ludzi. Ci jednak, którzy takiego daru nie otrzymali, nie powinni wątpić w swoją przynależność do Niego, iż jakoby nie byli godni, w przeciwieństwie do innych, otrzymania takich darów. Powód znajduje się raczej nie w nich, ale w woli Pana. Wszyscy stanowią jedno Ciało, w którym każdy członek ma inne zadania i zdolności. A zatem nie z powodu tych darów mają się cieszyć Apostołowie, ale dlatego, że ich imiona zapisane są w niebie ${ }^{9}$. Tajemnica Kościoła jako Ciała Chrystusa pokazuje, że czymś bardziej podstawowym jest jedność w tym Ciele aniżeli wzajemna wymiana darów przez różne Jego członki. Antycypacją zapisu w niebie staje się w jakiś sposób zapisanie do wspólnoty Kościoła.

6. Ważniejsze uczynki sprawiedliwości. Augustyn podkreśla, że poza wiarą i miłością, a więc cnotami, także dzieła dobra, będące owocem cnoty sprawiedliwości, mają większą wartość niż same cuda. Bóg nie obdarza wszystkich świętych zdolnością do czynienia cudów, aby słabsi w wierze nie odnieśli wrażenia, że tego rodzaju dzieła ,są większym darem niż uczynki sprawiedliwości”. Jezus w Łk 10, 20 przypomina, że życie wieczne zależy bardziej od tych drugich czynów niż od pierwszych ${ }^{10}$. Tę samą myśl wyraża na sposób poetycki Seduliusz:

„[...] Lecz cieszcie się, że w księdze wieczystej

Wasze imiona zapisze też litera niebiańska.

Prawem Bożym przecież jest stawiać życie przed czynami.

Bo gdy dobro należne ustaje, cuda są niczym,

Spełniają je najczęściej źli, do których Sędzia świata

Skieruje takie słowa: «Nie znam was, odejdźcie wszyscy

${ }^{8}$ Augustinus, In Joannis Evangelium tractatus 13, 17, ed. D.R. Willems, CCL 36, Turnholti 1954, 140, thum. W. Szołdrski: Św. Augustyn, Homilie na Ewangelię św. Jana, PSP 15/1, Warszawa $1977,210$.

${ }^{9}$ Por. tenże, Sermo 142, ed. G. Morin, MA I 702.

${ }^{10}$ Por. tenże, De diversis quaestionibus octoginta tribus 79, 3, ed. A. Mutzenbecher, CCL 44A, Turnholti 1975, 228. 
Sprawcy niegodziwości, którzy zawsze w nieprawości

Udajecie dzieło Boże»; tak też w czasach Mojżesza

Niektórzy zaklęciami w okolicy zwodniczego

Memfis dawali znaki nie za zgodą Boga, lecz fałsz

Pokazywali oczom ludzkim w magicznych figurach"11.

7. Wymaga się czystości życia i serca. Jakie to są uczynki sprawiedliwości, większe od cudów? Ojcowie podkreślają, że dla owego niebiańskiego zapisu liczy się całokształt życia. Apostołowie nie powinni się zbytnio cieszyć $\mathrm{z}$ dokonanych uzdrowien,

„bo nie sprawiła tego ich własna potęga, lecz moc Imienia, którego wzywali”.

Dlatego Chrystus napomina:

„aby się nie ważyli rościć sobie jakiejś szczęśliwości lub chwały za rzeczy, które sprawia jedynie moc i potęga Boga, lecz raczej za ową szczerą czystość życia i serca, dla której imiona ich mają być zapisane w niebiosach"12.

Dla osiaggnięcia duchowej radości nie wystarczy wykorzenić namiętności, ale trzeba też zdobyć cnoty, idąc za łaską usynowienia przez Boga ${ }^{13}$. Chrześcijanin, pomny na niebieski zapis, praktykuje uczciwość, niewinność, asceze i wiarę ${ }^{14}$. Zanim zapiszą go na trwałe w niebie, stara się, aby już teraz $\mathrm{w}$ nim zostało odciśnięte coś trwałego - nie tylko znamię Bożej łaski, lecz jego własnych cnót oraz czynów. Zapisane zostaną imiona tych, którzy akceptowali prawo boskie i je wypełniali ${ }^{15}$.

8. Sprawiedliwi są zapisani w niebie jak gwiazdy. W związku z etosem sprawiedliwości, na Jezusową obietnicę uwiecznienia sprawiedliwych nakłada się biblijne porównanie sprawiedliwych do gwiazd świecących na niebie. Te dwie rzeczy łączy na przykład Augustyn, porównując Apostołów wracających z misji do gwiazd, których niezliczoną ilość Bóg określa i nadaje każdej własne imię (Ps 147(146), 4) ${ }^{16}$. Kasjodor wiąże wypowiedź w Łk 10, 20 z zapowiedzią Jezusa w Mt 13, 43 o sprawiedliwych mających świecić ,jak

${ }^{11}$ Sedulius Caelius, Paschale carmen IV 161-171, tłum. H. Wójtowicz, w: Sedulius Caelius, Opera omnia. Dzieła wszystkie. Tekst łacińsko-polski, Lublin 1999, 177.

12 Joannes Cassianus, Collationes Patrum XV 9, ed. M. Petschenig, CSEL 17, Vindobonae 1888, 432, tłum. L. Wrzoł: Jan Kasjan, Rozmów dwadzieścia cztery, POK 7, Poznań 1926, 149.

${ }^{13}$ Por. Maximus Confessor, Capita theologica et oecumenica I 77, PG 90, 1084-1173.

${ }^{14}$ Por. Gregorius Nazianzenus, Carmina historica de se ipso et quae spectant ad alios II 333, PG 37, 1599.

${ }^{15}$ Por. Filastrius, Diversarum hereseon liber 137, ed. F. Heylen, CCL 9, Turnholti 1957, 301-302.

${ }^{16}$ Por. Augustinus, Enarrationes in Ps. 146, 10, ed. D.E. Dekkers - I. Fraipont, CCL 40, Turnholti 1956, 2129. 
gwiazdy na niebie" (Dn 12, 3) ${ }^{17}$. Beda Czcigodny nie tyle w gwiazdach, co w obłokach oświetlonych przez „słońce sprawiedliwości”, którym jest Chrystus, dostrzega obraz świętych zapisanych $w$ niebie ${ }^{18}$. To nie imiona bezbożnych, ale świętych zostaną zapisane w niebie ${ }^{19}$. W Łk 10, 20 odnajdujemy zapowiedź nowego świata:

„I nie dziwi to już, jeśli w tym nowym świecie jest mnóstwo gwiazd, policzonych i ponazywanych przez Boga, a ich imiona zostały zapisane w niebie przez ich Stwórcę. To bowiem usłyszałem, gdy Stworzyciel nowego stworzenia mówił do swoich źródeł światła: «Wasze imiona zapisane są w niebie»" ${ }^{20}$.

Grzegorz z Nyssy ma zapewne na myśli sprawiedliwych, którzy będąjak gwiazdy jaśnieć w chwalebnej rzeczywistości. Dodajmy, że obraz sprawiedliwych jako gwiazd w starożytności chrześcijańskiej nie musiał być tylko czystą metafora. W spekulacjach orygenesowskich gwiazdy uchodziły za byty rozumne.

9. Szatan z kolei spadł niczym jutrzenka. Tymczasem upadek szatana pokazuje odwrotny los. Będąc władcą świata, wschodząc rano pośród innych gwiazd jak jutrzenka (Lucifer), z udzielonej przez Boga wielkości spadł do rangi odrzuconego przez Boga. Zamiast wschodzić - zszedł. Jego los jest dla uczniów Jezusa przestrogą. Według Hieronima zapisane w niebie imiona uczniów kojarzą się z wcześniejszym wyniesieniem tego Władcy pośród niebieskich duchów. Mają oni pozyskać obiecane przez Jezusa niebo, z którego spadł szatan, dzięki postawie, jakiej zabrakło szatanowi, mianowicie wstępując tam przez pokorę ${ }^{21}$.

10. Więcej znaczy wypędzić z siebie grzech. Chryzostom w błyskotliwy sposób zestawia wartość cudów z cudem własnej przemiany:

„Nie jest rzeczą tak wielką uwolnić od demona jak wyzwolić się z grzechu. Demon nie przeszkadza w osiągnięciu królestwa Bożego, lecz nawet, mimowolnie, pomaga, czyniąc skromniejszym ( $\sigma \omega \varphi \rho \circ v \eta ́ \sigma \tau \varepsilon \rho o v)$ tego, kogo posia-

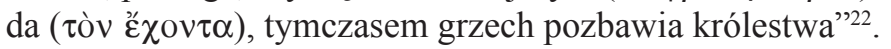

Jeśli autor przez posiadanie ma na myśli demoniczną obsesję czy jakąś inną

\footnotetext{
${ }^{17}$ Cassiodorus, Expositio Ps. 146, 4, ed. M. Adriaen, CCL 98, Turnholti 1958, 1306.

${ }^{18}$ Por. Beda Venerabilis, In principium Genesis usque ad nativitatem Isaac II 9, ed. C.W. Jones, CCL 118A, Turnholti 1967, 135.

${ }^{19}$ Por. Anonymus, Quaestiones vel Glosae in evangelio nomine 50, ed. R.E. McVally, CCL 108B, Turnholti 1973, 144.

${ }^{20}$ Gregorius Nyssenus, In Canticum canticorum hom. XIII, GNO 6, 385, thum. M. Przyszychowska: Grzegorz z Nyssy, Homilie do Pieśni nad Pieśniami, ŹMT 43, Kraków 2007, 200.

${ }^{21}$ Por. Hieronymus, Commentarii in Esaiam VI 14, 12, ed. M. Adriaen, CCL 73, Turnholti 1963, 240; zob. Beda Venerabilis, In Lucae evangelium expositio III 10, 20, CCL 120, 219.

${ }^{22}$ Joannes Chrysostomus, In Acta Apostolorum hom. 41, 3, PG 60, 292, thum. własne.
} 
formę nękania, to z wypowiedzi wynika pogląd, że takie działanie demona nie jest tak groźne jak grzech. Może ono do jakiegoś stopnia dokonać się wbrew woli człowieka i dlatego nie powoduje takiej winy jak tamto, a nadto uczy pokory.

11. Wartość ascezy. Czynienie znaków zostaje porównane nie tylko z uczynkami o charakterze moralnym, ale także ascetycznym. Według Atanazego Aleksandryjskiego te dwie rzeczy konfrontował ze sobąAntoni Pustelnik:

„Nie należy się chełpić z powodu pokonania złych duchów ani też pysznić się uzdrawianiem. Nie należy podziwiać tego, który złe duchy wypędza, ani tego, który nie wypędza, lekceważyć. Niech każdy pozna ascezę drugiego i albo naśladuje, albo z nim współzawodniczy, albo poprawia. Znaki bowiem nie są dziełem naszym, lecz Pana [...]. To, że imiona nasze są w niebie zapisane, to jest świadectwem naszej ascezy i życia. Wyrzucanie demonów jest łaską daną przez Zbawiciela"23.

Antoni Opat postulował neutralną postawę względem nadprzyrodzonych charyzmatów, które są udziałem innych. Nie są one zasługą człowieka, ale Boga. Czym człowiek może się cieszyć i w czym współzawodniczyć z innymi, to własne życie moralne i ascetyczne.

12. Większym cudem pociągnąć innych do nieba. Po linii tej samej interpretacji Ambroży Autpert podkreśla, że największym cudem jest wyrzeczenie się świata całym umysłem. Wielu uczestniczy w cudach, ale niekoniecznie ich imiona są zapisane w niebie. Nie tyle doraźnych cudów szuka się w Kościele, co życia doskonałego. U autora pobrzmiewa akcent misyjny. Wielkim cudem jest pociągnąć niezliczonych ludzi przykładem swego życia i

„wznieść ich z ziemi do nieba, z ciemności do światła, ze śmierci do życia, zaprowadzić z wygnania do ojczyzny"24.

Ambroży zdaje się dopatrywać w działaniu człowieka, w jego postępowaniu - nie wykluczając innych rzeczy - racji, dla której Bóg zapisuje go w swojej pamięci. Przekładając słowa Jezusa na grunt ascetyczny, w jakiś sposób zawęża ich sens. $Z$ drugiej jednak strony, pokazując ascezę jako środek misyjnego oddziaływania, pozostaje w obrębie misyjnego kontekstu Łk 10, 20.

13. Cieszyć się ze zbawienia innych. Z kolei u Tertuliana, już bez szczególnego odniesienia do ascezy, ów sens misyjny wybrzmiewa jeszcze bardziej:

${ }^{23}$ Athanasius Alexandrinus, Vita Antonii 38, PG 26, 897, thum. E. Dąbrowska: Św. Antoni, Żywot, ŹM 35, Kraków 2005, 109.

${ }^{24}$ Ambrosius Autpertus, Vita sanctorum patrum Paldonis, Tatonis et Tasonis 14, ed. R. Weber, CCCM 27B, Turnholti 1979, 901, thum. własne. 
„Przecież nie chciał [Chrystus], aby nawet Jego uczniowie chwalili się z tego, że im były poddane złe duchy, ale z jaśniejącego przez nich zbawienia" ${ }^{25}$.

Powodem do nadprzyrodzonej radości mają być dla uczniów Chrystusa nie tyle znaki towarzyszące ich misyjnej działalności, które są dopiero środkiem do celu, ale sam cel, to jest dobro zbawienia. Wypędzać złe duchy mogą nieraz ludzie niesprawiedliwi, wprowadzając siebie i innych w błąd ${ }^{26}$. Jeśli sprawiedliwi czynią niekiedy takie rzeczy, to na przykład różnią się zdecydowanie od magów dokonujących czegoś podobnego. Różnią się przyczyną i celem, dla których to czynią. Sprawiedliwi dokonują znaków z mandatu Chrystusa, dla ogólnego dobra i chwały Bożej, tymczasem magowie - dla własnej chwały i korzyści ${ }^{27}$. Tak więc uczniowie Chrystusa o wiele bardziej niż z samych cudów mają cieszyć się z tego, czemu cuda służyły, mianowicie z wiary tych, którzy uznali Chrystusa za Syna Bożego dzięki świadectwu Ducha Świętego danemu przez ich słowo ${ }^{28}$.

14. Przez chrzest człowiek rodzi się dla nieba. Zapowiadany przez Chrystusa zapis w niebie staje się dla Bedy Czcigodnego synonimem chrztu. Autor oddaje misyjnego ducha swoich czasów, gdy wskazuje na rozbrzmiewające z krańców ziemi wołanie pogańskich narodów, które Bóg wysłuchuje i czyni je częścią swego stada. Na całym świecie rozbłyska światło poznania niesione przez Kościół. Imiona przychodzących ludzi Bóg zapisuje w niebie i nazywa ich swoimi owcami ${ }^{29}$. Nie zestawiając z niczym, angielski mnich wskazuje na nieporównywalną wartość chrzcielnego odrodzenia. Klemens Aleksandryjski wskazuje na to najbardziej elementarne dzieło, większe od cudów, a dające tytuł do obywatelstwa w nadprzyrodzonej wspólnocie:

„Jeżeli [uczniowie Chrystusa] odrzucili wszystko, co z dawna piastowali w swoim umyśle i co było chorobą ich duszy, i tak idą w ślady Nauczyciela, to takie postępowanie byłoby godne już ludzi, których imiona mają być zapisane w niebie" ${ }^{\prime 3}$.

Dziełem godnym człowieka jest jego odrodzenie.

${ }^{25}$ Tertullianus, Adversus Marcionem IV 7, 13, ed. A. Kroymann, CSEL 47, Vindobonae 1906, 437, tłum. S. Ryznar: Tertulian, Przeciw Marcjonowi, PSP 58, Warszawa 1994, 152.

${ }^{26}$ Por. Ps-Clemens Romanus, Homiliae 9, 22, ed. B. Rehm, GCS 42bis, Berlin 1969, 140.

${ }^{27}$ Por. Augustinus, De diversis quaestionibus 79, 3, CCL 44A, 228.

${ }^{28}$ Por. Cyrillus Alexandrinus, Commentarii in Lucam 64, ed. R. Payne Smith: Commentarii in Lucae evangelium quae supersunt syriace e manuscriptis apud Museum Britannicum, Oxford 1858, 30.

${ }^{29}$ Por. Beda Venerabilis, In Samuelem prophetam allegorica expositio I 7, 12, ed. D. Hurst, CCL 119, Turnholti 1962, 63n.

${ }^{30}$ Clemens Alexandrinus, Quis dives salvetur 21, ed. O. Stählin - L. Früchtel, GCS 17bis, Berlin 1970, 174, tłum. J. Czuj: Klemens Aleksandryjski, Czy człowiek bogaty może być zbawiony?, Kraków - Ząbki 1995, 77. 
15. Patrzeć naprzód przez pryzmat krzyża. Skoro dotykamy ascezy, wyrzeczenia, to w perspektywie pojawia się tajemnica krzyża. Nie chodzi w niej tylko o zaparcie się siebie przez umartwienie, ale także o cierpliwość w znoszeniu cierpień przychodzących mimowolnie, aż po wytrwałość w prześladowaniach. Uczniowie nie powinni cieszyć się oglądając się wstecz, z uczynionych znaków, ale cieszyć się patrząc naprzód, że „stali się godni cierpieć dla imienia Jezusa" (Dz 5, 41) ${ }^{31}$.

16. Wpływ Orygenesa? Orygenes zdaje się podsumowywać wszystkie wyżej zaprezentowane rzeczy, które inni autorzy porównują i stawiają wyżej niż cuda. Stwierdza, że należy radować się z tymi, którzy dokonują

„dzieła zasługującego na zapisanie w niebie, dzieła sprawiedliwości, miłości,

pokoju lub miłosierdzia, czy też osobistego nawrócenia"'32.

Duża zbieżność tej listy, nawet pod względem werbalnym, z tą listą która wynika z myśli innych autorów, każe sądzić, że przynajmniej jakaś część pisarzy mogła bezpośrednio inspirować się przytoczonym zestawieniem Orygenesa.

\section{KSIĘGA ŻYJĄCYCH I KSIĘGA SPRAWIEDLIWYCH}

Podobny wpływ Orygenesa zdaje się występować w innym wątku interpretacji Łk 10, 20. Ulubioną praktyką Ojców jest łączenie użytego przez Chrystusa obrazu zapisania imion w niebie z zapisaniem do ,księgi żyjących i sprawiedliwych".

1. Zapisani $\mathbf{w}$ niebie to usprawiedliwieni $\mathbf{z}$ wiary. Na przykład Hilary z Poitiers wyobraża sobie niebiański zapis jako wpis do księgi. Odwołuje się do Ps 68, 29 (LXX): „Niechaj będą wymazani z ksiąg żyjących, a niech nie będą wpisani razem ze sprawiedliwymi”. Rozróżnia za Psalmistą „księgę żyjących” i „księgę sprawiedliwych”. Do tej pierwszej zapisani są ci, którzy żyli przed Chrystusem i starali się wypełniać wymogi Prawa: „Kto je wypełni, osiagnie przez nie życie" (Rz 10,5). Może i niewykluczony jest szerszy sens: do księgi tej zapisani są wszyscy powołani do istnienia $\mathrm{i}$ - na mocy natury do życia zgodnego ze swoim sumieniem. Tymczasem w „księdze sprawiedliwych” zostali zapisani ci, których sprawiedliwością stał się Chrystus: „sprawiedliwy żyć będzie dzięki wierze" (Ga 3,11). Tę drugą księgę ma na myśli Chrystus w Łk 10, 20. Zdaniem galijskiego teologa, skierowana do Apostołów zachęta do wielkiej radości sugeruje, że więcej znaczy to,

\footnotetext{
${ }^{31}$ Por. Joannes Chrysostomus, In Acta Apostolorum hom. 31, 1, PG 60, 229.

${ }^{32}$ Origenes, Commentarii in Epistulam ad Romanos 9, 15, PG 14, 1221, thum. S. Kalinkowski: Orygenes, Komentarz do Listu św. Pawła do Rzymian, PSP 57/2, Warszawa 1994, 479.
} 
„iż zostali zapisani w księdze sprawiedliwych, aniżeli to, iż nie zostali usunięci z księgi żyjących"33.

$\mathrm{Z}$ pomocą w zrozumieniu tego zagadkowego zdania przychodzi Euzebiusz z Cezarei, uczeń Orygenesa, który stwierdza, że Bóg zapisuje ludzi do księgi życia „,na mocy ich własnej sprawiedliwości”. Zostaną skreśleni z niej ci, „którzy wyrzekliby się Władcy życia”"34. Jeśli istnieje pokrewieństwo między tymi wypowiedziami, to trzeba widzieć w słowach Hilarego co najmniej trzystopniową gradację ludzkiego statusu. Po pierwsze, człowiek jest najpierw zapisany do księgi życia. To leży w gestii Boga, który wybiera kogoś, jak niektórzy sądzą, ze względu na jego przyszłe dobre uczynki. Po drugie, człowiek nie zostaje usunięty z ,księgi żyjących" dzięki sprawiedliwości swoich czynów. Po trzecie, czymś większym od tych obydwu rzeczy jest być zapisanym w księdze sprawiedliwych. Tutaj wszystko zależy od Boga Zbawcy - zarówno nie być z niej skreślonym, jak i zostać do niej zapisanym. Chodzi bowiem o usprawiedliwienie w Jezusie Chrystusie, choć ludzka postawa nie jest też bez znaczenia. Hilary wyraża przekonanie, że większym darem jest usprawiedliwienie przez wiarę i życie w Chrystusie aniżeli pierwotne wybranie w Starym Przymierzu i wstępne przeznaczenie do zbawienia. Ponadto autor podkreśla, że czynnikiem decydującym w zbawieniu jest wiara, a nie uczynki. Do takiej postawy wychowuje Jezus uczniów, gdy odwraca ich uwagę od ich własnych zasług, a każe liczyć na usprawiedliwienie przez łaskę.

2. Judasz wymazany z księgi sprawiedliwych. Biskup Poitiers w powyższym fragmencie wskazuje też na odwrotną sytuację. Jak istnieje podwójna kategoria zbawionych, tak istnieje podwójna kategoria tych, którzy są pozbawieni tego dobra, mianowicie ci, którzy mają być usunięci z „,księgi żyjących”, i ci, którzy wprawdzie nie zostali z niej usunięci, ale też nie będą zapisani w ,księdze sprawiedliwych"35. Być może Hilary rozszerza tu sens zapisu do „księgi żyjących”, mając na myśli wszystkich ludzi obdarzonych istnieniem, niezależnie od sposobu życia. Nie wszyscy z nich zostaną zapisani do „księgi sprawiedliwych", czyli zostaną zbawieni. Chryzostom zwraca się do słuchacza: „Widzisz, jak jedni zostają wymazani, drudzy zaś zapisani?"36 Zdaniem Bedy Czcigodnego bezbożni będą wykreśleni z księgi żyjących, a sprawiedliwi zostaną zapisani w wiecznej pamięci Boga ${ }^{37}$. Jan Kasjan pokazuje konkret-

${ }^{33}$ Hilarius Pictaviensis, Tractatus super Ps. 68, 24, ed. J. Doignon, CCL 61, Turnholti 1997, 310, thum własne.

${ }^{34}$ Eusebius Caesariensis, Commentarii in Ps. 68, 29, PG 23, 757, thum. własne.

${ }^{35}$ Por. Hilarius Pictaviensis, Tractatus super Ps. 68, 24, CCL 61, 310n.

${ }^{36}$ Joannes Chrysostomos, De Sancta Pentecoste 1, 6, PG 50, 462, thum. W. Kania, w: Św. Jan Chryzostom, Homilie i kazania wybrane, PSP 8, Warszawa 1971, 134.

${ }^{37}$ Por. Beda Venerabilis, Explanatio Apocalypsis II 24, 14, 13, ed. R. Gryson, CCL 121A, Turnholti 2001, 431. 
nie ludzi, dla których zabraknie miejsca w obydwu księgach. Są nimi Judasz i prześladowcy Chrystusa, którzy zostaną wymazani z księgi żyjących i nie zostaną zapisani w księdze sprawiedliwych.

„Na Judaszu okazała się też oczywiście siła tego proroczego przekleństwa. Albowiem wykonawszy zbrodnię zdrady, «powiesił się» (Mt 27, 5), aby po owym wymazaniu jego imienia nie nawrócił się i nie zasłużył na nowo na zapisanie w poczet sprawiedliwych $w$ niebie. Nie należy więc wątpić, że także imię Judasza w czasie gdy został przez Chrystusa wybrany i uzyskał stopień apostolstwa, było zapisane w księdze żyjących" ${ }^{\text {"38 }}$.

Polemizując być może z Augustyńskim predystynacjonizmem, Kasjan podkreśla, że Judasz zawsze miał możliwość zawrócenia z drogi zła. Był przeznaczony do zbawienia i zapisany w księdze żyjących, a chociaż sam wymazał się z księgi sprawiedliwych, mógł do niej ponownie się zapisać. W katenach Prokopa z Gazy przestrzega się przed złym użyciem własnej wolności. Jeśli Pismo Święte dostrzega możliwość wykreślenia z księgi życia, oznacza to stan, w którym człowiek, przechodząc z cnoty do zła, wpływa na zmianę zapisu. Kateny wskazują przy tym na $\mathrm{Wj} 32,32$, gdzie przestrzega się przed taką zmianą̧ ${ }^{39}$, podczas gdy Bazyli wyrażając podobną myśl powołuje się na Wj 32, 32 oraz Ps 69(68), 29. Póki człowiek żyje, zapis nie jest definitywny, bo można utracić zapis do księgi życia ${ }^{40}$ albo go też odzyskać.

3. Orygenesowskie inspiracje. Zapewne Hilary, korzystając z powyższego biblijnego rozróżnienia, odwołuje się do egzegetycznej tradycji, sięgającej co najmniej Orygenesa. Niekompletność pism Aleksandryjczyka nie pozwala na rekonstrukcję pełnej jego interpretacji odnośnego wątku. Na podstawie rozproszonych elementów tej myśli odnosimy wrażenie, że była ona dość bliska egzegecie. Stwierdzając, że poganie nie są zapisani do „księgi żyjących”41, zdaje się zdradzać pogląd nie odbiegający od przekonania swego naśladowcy, Hilarego. Do księgi żyjących należą wybrani przez Boga ludzie, których Bóg uzdalnia do życia sprawiedliwego. Radykalniejszą myśl spotykamy w katenach Prokopa z Gazy, iż mianowicie istnieje dwojaki zapis, jeden dla tych, którzy są zapisani do życia, a których nawet włosy na głowie są policzone, a drugi dla zapisanych na zagładę ${ }^{42}$. Augustyn zagospodaruje tę ideę dwojakiego przeznaczenia na użytek swojej doktryny o przeznaczeniu i łasce. Zapis do księgi życia to pierwotne przeznaczenie człowieka przez Boga do zbawienia $^{43}$. Tomasz z Akwinu, przejmując ideę księgi życia jako dojrzały już owoc

\footnotetext{
${ }^{38}$ Joannes Cassianus, Collationes Patrum XVII 25, 17-18, CSEL 13, 496, POK 7, 224-225.

${ }^{39}$ Por. Procopius Gazaeus, Commentarii in Numeros, PG 87, 795-796.

${ }^{40}$ Por. Basilius Caesariensis, Enarratio in prophetam Esaiam IV 137, PG 30, 340.

${ }^{41}$ Por. Origenes, Fragmenta in diversos Psalmos in catenis in Ps 9, 6, PG 12, 1188.

${ }_{42}$ Por. Procopius Gazaeus, Commentarii in Numeros, PG 87, 795-796.

${ }^{43}$ Por. Augustinus, De civitate Dei XX 15, ed. B. Dombart - A. Kalb, CCL 48, Turnholti 1955,
} 
spuścizny patrystycznej, poświęci jej kilka artykułów Sumy teologicznej ${ }^{44}$. Jak widzimy, spekulacje Ojców na temat księgi życia i księgi sprawiedliwości są dość bogate, choć niejednorodne. Ich egzegeza Ps 68, 29 - wzięta całościowo, w całej swej rozmaitości, i zastosowana do Łk 10, 20 - niekoniecznie ułatwia zrozumienie rozpatrywanych słów Jezusa. Jej zasługą jest to, że prowokuje do nowych przemyśleń.

4. Chrystus na ziemi zapisuje do nieba. U Orygenesa spotykamy myśl, która chrystocentrycznie wieńczy patrystyczne dociekania na temat symboliki księgi żyjących i sprawiedliwych. Aleksandryjczyk dostrzega pewien związek między owymi księgami a spisem ludności, któremu został poddany Jezus po swoim narodzeniu (Łk 2, 1-2). W spisie ludności za Cezara Augusta widzi doniosły obraz Wcielenia:

„Chrystus został zapisany na listę mieszkańców całego świata, aby, zapisany razem ze wszystkimi, uświęcił wszystkich i, wpisany do rejestru świata, udzielił światu łączności ze sobą, aby po tym spisie wpisał wszystkich ludzi razem ze sobą «do księgi żyjących», aby wszyscy, którzy w Niego uwierzyli, zostali później zapisani w niebiosach razem ze świętymi”"45.

Wyłania się teologia wymiany. Bóg wchodzi do społeczności ludzkiej, aby człowiek mógł dostapić obywatelstwa w Jego społeczności. Za Orygenesem idą Ojcowie Kapadoccy, podobnie kojarząc spis, w którym zostali spisani Maryja i Józef, ze spisem, przez który zostaliśmy zapisani do nieba ${ }^{46}$. W tym drugim spisie Chrystus nie jest biernym uczestnikiem, ale jego wykonawca. Bowiem Boże Dziecię Jezus zapisuje w niebie imiona tych, którzy odwrócili się od zła i przez pokutę stali się godni poznania Boga ${ }^{47}$.

5. Zapisani w niebie a zapisani na ziemi. W zachowanych resztkach egzegezy Orygenesa rozróżniającego pomiędzy „księgą żyjących” i „księgą sprawiedliwych" spotykamy dowód łączenia tego zestawienia z pokrewną dystynkcją pomiędzy zapisaniem na ziemi i zapisaniem w niebie. Podczas gdy Chrystus zapisuje imiona uczniów w niebie, niegodziwy zarządca zapisuje

726, tłum. W. Kubicki: Augustyn, Państwo Boże, Kęty 1998², 826.

${ }^{44}$ Por. Thoma de Aquino, Summa Theologiae I, q. 24, 1-3, ed.: Sancti Thomae Aquinatis Doctoris Angelici Opera omnia iussu impensaque Leonis XIII P.M. edita, t. 4: Pars Prima Summae theologiae a quaestione I ad quaestionem XLIX, Romae 1888, 286-288, tłum. P. Bełch, w: Tomasz z Akwinu, Suma teologiczna. O Bogu, I, q. 13-26, t. 2, Londyn 1977, 84-86.

${ }^{45}$ Origenes, In Lucam hom. 11, 6, ed. M. Rauer, GCS 49, Berlin 1959, 71, thum. S. Kalinkowski: Orygenes, Homilie o Ewangelii św. Łukasza, PSP 36, Warszawa 1986, 61.

${ }^{46}$ Por. Gregorius Nazianzenus, Oratio 38, 17, PG 36, 332, thum. zbiorowe, w: Św. Grzegorz z Nazjanzu, Mowy wybrane, Warszawa 1967, 424.

${ }^{47}$ Por. Basilius Caesariensis, Enarratio in prophetam Esaiam 10, 244, PG 30, 545-546. 
imiona swoich dłużników na ziemi, w księdze umarłych ${ }^{48}$.

„Człowiek zatem powinien się cieszyć, jeśli stał się takim, iż imię jego może zostać zapisane w niebie. A jak imię świętych jest zapisywane w niebie, tak imiona tych, którzy żyją na sposób ziemski, [...] zostają zapisane w ziemi, bo opuścili Boga" ${ }^{\text {49. }}$.

Wątek ten podejmują też inni autorzy inspirujący się Orygenesem. Dydym Ślepiec rozróżnia pomiędzy uczestnikami życia wiecznego, na przykład Apostołami, których imiona są zapisane w niebie, oraz tymi, którzy zginą, zgodnie z Ps 49(48), 12, bo ich imiona zapisane są tylko na ziemi. Imiona zostają zapisane $\mathrm{w}$ zależności od postępowania i myślenia ${ }^{50}$. Pamięć o źle czyniących zostanie wypleniona z ziemi (Ps 34(33), 17), a ci, którzy zwracają się ku cnocie, zostaną uwiecznieni przez Boga ${ }^{51}$. Tak samo według Ambrożego imiona tych pierwszych są zapisane na ziemi, ponieważ ich czyny są ziemskie i przemijające. Tam są zapisane ich imiona, gdzie chcieli żyć. Natomiast imiona tych, którzy uszlachetnili (elevaverunt) swoje czyny, są zapisane w niebie ${ }^{52}$.

6. Jezus zapisuje faryzeuszy na ziemi. Ideę zapisu grzeszników na ziemi, w przeciwieństwie do uwiecznienia sprawiedliwych w niebie, uzasadniają Ojcowie gestem Jezusa piszącego „palcem po ziemi” (J 8, 6). Jak wskazuje Ambroży, kiedy Żydzi oskarżali kobietę cudzołożną, ponieważ byli synami tej ziemi, Jezus zapisywał ich niejako na ziemi. „Sprawiedliwi tymczasem nie są zapisywani na ziemi”, ale ich imiona są zapisane w niebie ${ }^{53}$. Podobnie Augustyn rozróżniając pomiędzy zapisanymi w niebie i na ziemi, za tych drugich uznaje oskarżycieli jawnogrzesznicy ${ }^{54}$.

7. W Jr 17, 13 ostrzega się przed odstępstwem. Augustyn, a także inni, dopatrują się potwierdzenia losu ludzi żyjących po ziemsku nie tylko w J 8,6, ale już w Jr 17, 13: „Ci, którzy oddalają się od Ciebie, będą zapisani na zie-

${ }^{48}$ Por. Origenes, Fragmenta in diversos Psalmos in catenis in Ps 9, 6, PG 12, 1188.

${ }^{49}$ Tenże, In Ieremiam hom. 17, 4, ed. E. Klostermann, GCS 6, Leipzig 1901, 146-147, thum. S. Kalinkowski: Orygenes, Homilie 1-20 o Księdze Jeremiasza, PSP 30, Warszawa 1983, 147.

${ }^{50}$ Por. Didymus Alexandrinus, Fragmenta in Ps. 511, in Ps. 48, 12c, ed. E. Mühlenberg, Psalmenkommentare aus der Katenenüberlieferung, Berlin - New York 1975, 359.

${ }^{51}$ Por. tenże, Commentarii in Iob (1-4) 63, 14, ed. A. Henrichs: Didymos der Blinde, Kommentar zu Hiob (Tura-Papyrus), 1, Kommentar zu Hiob Kap. 1-4, Bonn 1968, 192.

${ }^{52}$ Por. Ambrosius, Explanatio super Ps. 48, 18, ed. M. Petschenig, CSEL 64, Vindobonae $1999^{2}, 372$.

${ }^{53}$ Por. tenże, De interpellatione Iob et David IV 5, 20, ed. C. Schenk1, CSEL 32/2, Vindobonae 1897, 282; tenże, Epistula IX 68, 14, ed. G. Banterle, SAEMO 20, 200, thum. P. Nowak: Św. Ambroży z Mediolanu, Listy, BOK 20, Kraków 2003, 134.

${ }^{54}$ Por. Augustinus, Contra adversarium legis et prophetarum I 20, 43, ed. K.D. Daur, CCL 49, Turnholti 1985, 76 . 
mi”55. Na zapowiedź Jeremiasza powołuje się Grzegorz Wielki. „Odstępujący od Boga" będą zapisani na ziemi, bo nie pamiętają o sprawach nieba, a pragną jedynie ziemskich rzeczy. Gdy starają się, aby więcej było widziane, mniejszym jest to, czego pragna. Tymczasem Jego wybrani są zapisani w niebie ${ }^{56}$. Godne uwagi, że Grzegorz Wielki mówiąc o recedentes a Deo nie ma na myśli odstępców od wiary, ale tych, którzy przez przyziemne myśli coraz bardziej oddalają się od Boga. Bóg nie zapisze ich dzieł w swojej pamięci.

8. Obrazu zapisu nie traktować dosłownie. Kilku autorów sprzeciwia się takiej interpretacji Jr 17, 13, w której ktoś zbyt literalnie i niewolniczo trzyma się obrazu ziemskiego i niebieskiego zapisu. Jak stwierdza Dydym Ślepiec, imiona tych, którzy rozumują i postępują po ziemsku, troszcząc się jedynie o ziemskie sprawy, zostaną zapisane pośród ziemskich rzeczy. Co do imion sprawiedliwych, to nie imiona złożone z sylab zostaną uwiecznione, ale imiona w sensie duchowym, nadane przez cnotę ${ }^{57}$. Przez imię wyraża się duchową jakość. Imię jest zwięzłą charakterystyką tego, kogo nim się nazywa. Tu chodzi o „człowieka niebieskiego”, który zostanie przyjęty do nieba ${ }^{58}$. Podobnie Beda Czcigodny, nie tyle wysuwając własne zastrzeżenia, co powtarzając krytykę swoich poprzedników, nazywa dziecinną interpretację $\mathrm{Jr}$ $17,13 \mathrm{w}$ takim sensie, że dobrzy mieliby zostać zapisani w niebie, a źli na ziemi. Rozsądek każe wnioskować, że dzieła człowieka, „czy to niebiańskie czy ziemskie", będą niczym literami zapisane w wiecznej pamięci Boga ${ }^{59}$. Nie wydaje się, żeby przedstawieni powyżej interpretatorzy nie byli świadomi metaforycznego charakteru tego rodzaju obrazów. Być może jednak istniało jakieś rzeczywiste nadużycie w egzegezie tego miejsca, skoro kilku pisarzy podnosi głos krytyki.

\section{SENS JEZUSOWEJ ZAPOWIEDZI}

Jak wynika z dotychczasowej analizy, refleksja Ojców skupia się bardziej na przyczynach, dla których wybranym przez Boga ludziom obiecuje się trwałość ich życia i dzieła. Nasi autorzy koncentrują się na wkładzie samego człowieka w spełnienie się tej obietnicy. Obecnie przeniesiemy uwage z powodu obietnicy na jej przedmiot, treść. Co w zasadzie obiecuje Chrystus, mówiąc o zapisie w niebie imion swoich uczniów? Już w przytoczonych

55 Tamże.

${ }^{56}$ Por. Gregorius Magnus, Moralia in Job XXV 8, 20, ed. M. Adriaen, CCL 143B, Turnholti $1985,1245$.

${ }^{57}$ Por. Didymus Alexandrinus, Commentarii in Genesim 16, 12, ed. P. Nautin - L. Doutreleau, SCh 244, Paris 1978, 228.

58 Por. tenże, Commentarii in Psalmos 35-39 264, 11-14, ed. M. Gronewald: Didymos der Blinde, Psalmenkommentar (Tura-Papyrus) 4, Kommentar zu Psalm 35-39, Bonn 1969, 160-162.

${ }^{59}$ Por. Beda Venerabilis, In Lucae evangelium expositio III 10, 20, CCL 120, 219. 
wypowiedziach wskazywało się na niebo, nowy świat i ojczyznę, królestwo Boże, górną Jerozolimę, szczęśliwość wieczną, chwałę zbawionych, obcowanie świętych. Szczególnie bogaty jest obraz nieba jako księgi sprawiedliwych, do której zostają zapisani wyznawcy Chrystusa. Wpisani są do niej wierzący w Niego, usprawiedliwieni na mocy Jego łaski. Przyjrzyjmy się tym świadectwom, w których obraz niebieskiego zapisu zostaje poddany głębszej refleksji.

1. Zapis do niebieskiej Jerozolimy. Niektórzy Ojcowie niebo w Łk 10, 20 utożsamiają z niebieską Jerozolimą. Bazyli Wielki, który, podobnie jak inni, posługuje się obrazem dwóch zapisów, jednego ku życiu, drugiego, ku zagładzie - powołując się na Jr 17, 13 - ten pierwszy zapis rozumie jako zapis do niebieskiej Jerozolimy ${ }^{60}$. Obraz Jerozolimy wyrażający niebiańskie przeznaczenie występuje także u innych Ojców. Zapisane w niebie imiona, to obywatele zapisani na listę niebieskiego Jeruzalem, zgodnie z Hbr 12, 22 ${ }^{61}$. Jeśli imiona Apostołów zostaną zapisane w niebie, to w niebieskim mieście Jeruzalem, w którym będą królować sprawiedliwi i święci ${ }^{62}$. Uwiecznienie imion oznacza udział w królestwie niebieskim ${ }^{63}$. Tamto obywatelstwo ma swój początek już teraz. Jezusowi powracającemu do rodzinnego miasta po misyjnej działalności w Galilei towarzyszyli uczniowie $($ Mk 6, 1) w tym sensie, że już należą oni, podobnie jak On, do wyższego porządku:

„tak wielkie wybranie i pełnia takiej łaski czyni ich obywatelami ojczyzny niebieskiej" ${ }^{64}$.

2. W Chrystusie Bóg o nas pamięta. Kilku pisarzy rozumie zapisane w niebie imiona jako zapamiętane przez Boga Ojca. Jezus zakazuje radości z powodu dokonanych znaków, aby uczniowie nie popadli w próżność, natomiast powodem radości mają być zasługi zapisane w „Ojcowskiej pamięci”" Beda Czcigodny, jak już przedstawiliśmy, tę wieczną pamięć Boga kojarzy z zapisem do księgi sprawiedliwych ${ }^{66}$. W katenach Prokopa czytamy:

„W Chrystusie jesteśmy dostrzegani przez Ojca i Chrystus sprawia, że Ojciec o nas pamięta" ${ }^{97}$.

To bogate w teologię zdanie ujmuje samą istotę prawdy wskazanej w Łk 10, 20.

\footnotetext{
${ }^{60}$ Por. Basilius Caesariensis, Enarratio in prophetam Esaiam 4, 137, PG 30, 340.

${ }^{61}$ Por. Didymus Alexandrinus, Commentarii in Zachariam II 149, ed. L. Doutreleau, SCh 84, Paris 1962, 490; zob. Procopius Gazaeus, Commentarii in Numeros, PG 87, 795-796.

${ }^{62}$ Por. Augustinus, De sermone Domini in monte II 25, 84, PL 34, 1307, thum. S. Ryznar - J. Sulowski: Św. Augustyn, O kazaniu Pana na Górze, PSP 48, Warszawa 1989, 128.

${ }^{63}$ Por. Filastrius, Diversarum hereseon liber 137, CCL 9, 302.

${ }^{64}$ Petrus Chrysologus, Sermo 49, 3, ed. A. Olivar, CCL 24, Turnholti 1975, 270, thum. własne.

${ }^{65}$ Anonymus, Commentarium in Lucam 10, 20, ed. J.F. Kelly, CCL 108C, Turnholti 1974, 75.

${ }^{66}$ Por. Beda Venerabilis, Explanatio Apocalypsis II 24, 14, 13, CCL 121A, 431.

${ }^{67}$ Procopius Gazaeus, Commentarii in Exodum, PG 87, 651n, thum. własne.
} 
Człowiek wybrany przez Boga, który nie sprzeniewierzył się swemu wybraniu, zostaje wpisany w pamięć, a właściwie całe życie Trójcy Świętej.

3. Chrystus nazywa i zna nas po imieniu. Padają w wypowiedziach akcenty chrystocentryczne. Euzebiusz z Cezarei wyjaśnia, że imiona Apostołów zapisane są w niebie, ponieważ nadał je sam Chrystus. Niektórym nadał indywidualnie, jak na przykład Piotrowi, a wszystkim - w sensie ogólnym, nazywając ich Apostołami $\left(Ł k\right.$ 6, 13) ${ }^{68}$. Zdaniem Augustyna Jezus mówiąc o imionach siedemdziesięciu dwóch uczniów zapisanych w niebie, wskazuje na to, że je

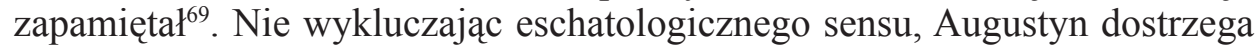
w słowach Jezusa pewien sens dosłowny. Jezus zapamiętuje imiona siedemdziesięciu dwóch uczniów powracających z misyjnej wyprawy. Bóg zna osobiście każdego, kto do Niego należy. Augustyn wiąże słowa Jezusa o imionach zapisanych w niebie z Jego wypowiedzią o owcach, które Dobry Pasterz woła po imieniu $(\mathrm{J} 10,3)$. On je poprzedza przez swoją śmierć, zmartwychwstanie i wniebowstapienie oraz prowadzi do wiecznego przeznaczenia ${ }^{70}$.

4. Bóg przeznacza nas do zbawienia. Zapisanie przez Boga jest synonimem Jego nieodwołalnego rozporządzenia (iudicatio). Jeśli Bóg zapisał imiona wybranych w niebie, to przede wszystkim w tym sensie, że przeznaczył ich do zbawienia. To, co Bóg zapisze, nie może zostać wytarte, gdyż jest oparte na przeznaczeniu. Żadna zewnętrzna okoliczność, żadne zdarzenie nie może zmienić wyroku boskiej opatrzności. Z tego powodu imiona uczniów Jezusa są zapisane w niebie i Bóg nie zmienia swego rozporządzenia, jeśli i oni nie zmienią się pod wpływem pobożnego zadowolenia z dokonanych cudów ${ }^{71}$. Rozporządzenie boskie pozostaje niezmienne, jeśli i człowiek się nie zmieni. Zdaniem Pseudo-Klemensa zapis w niebie ludzkich imion oznacza życie wieczne. Taki człowiek ma wielki powód do radości i cieszy się w Duchu Świętym, który podobnie odnajduje radość w tym, że „człowiek przewyższył śmierć” ${ }^{2}$. Chrystus nie chciał, żeby cieszyli się tym, co było ich „własnością, ale z tego, że razem z innymi mają zapewnione zbawienie". Powinni cieszyć się ze zbawienia otrzymanego na drodze wiary, miłości i pokory ${ }^{73}$.

5. Zapisani do Reszty Izraela. Niekiedy omawiani pisarze w niebiańskim zapisie dostrzegają spełnienie starotestamentalnej obietnicy, w której Bóg, wobec niewierności Izraela, zapowiedział szczególną zbawczą troskę nad

\footnotetext{
${ }^{68}$ Por. Eusebius Caesariensis, Commentarii in Ps. 71, 12, PG 23, 812.

${ }^{69}$ Por. Augustinus, Enarrationes in Ps. 91, 3, CCL 39, 1281.

${ }^{70}$ Por. tenże, In Joannis Evangelium tractatus 45, 14, CCL 36, 396; Anonymus, Commentarium in Joannem 10, 3, ed. J.F. Kelly, CCL 108C, Turnholti 1974, 120.

${ }^{71}$ Por. Cassiodorus, Expositio Ps. 68, 29, CCL 97, 619.

${ }^{72}$ Ps-Clemens Romanus, Homiliae 9, 22, GCS 42, 140, thum. własne.

${ }^{73}$ Por. Augustinus, Enarrationes in Ps. 130, 8, CCL 40, 1904.
} 
jego częścią, to jest Resztą. Jak powtarza Hieronim, nie cały Izrael dostąpi zbawienia, ale jego reszta na Syjonie, mianowicie każdy, kto zostanie „wpisany do [Księgi] Życia w Jeruzalem" (Iz 4, 3). Tą resztą są Apostołowie i ci, którzy przez nich uwierzyli. Ich imiona zostały zapisane w niebie. Ich grzech zostanie obmyty przez chrzest $^{74}$. Zdaniem Bedy Czcigodnego zapisane imiona uczniów Jezusa wskazują na ich pierwotny wybór przez Boga jako części Izraela, jako składnik żydowskiej synagogi. Właśnie ta synagoga miała od Boga wszystko dane, aby zrozumiała, przyjęła i wypełniła słowo głoszonej wiary. Jednak przez swój upór Żydzi nie uwierzyli Mistrzowi, lecz prowadzili złe życie i powzięli zły zamiar przeciwko Chrystusowi ${ }^{75}$. Zbawca czyni ze swoich uczniów zapowiadaną przez proroków Resztę, która dostapi zbawienia. $\mathrm{Na}$ drugi plan schodzą ich zasługi, a na pierwsze miejsce wysuwa się zbawcze działanie Boga. To, co z ich strony czyni ich godnymi zapisu w Izajaszowej Księdze, to wiara i chrzest.

6. Nowy Lud Izraela. Niektórzy symbolikę zapisania w niebie interpretują szerzej, wiążąc ją nie tyle z Resztą Izraela, co z całym Izraelem. Augustyn przekonuje swoich słuchaczy, że niebieskie wybranie dotyczy jakoś wszystkich chrześcijan. Po tym, jak Chrystus wstąpił do nieba, nie cali pozostaliśmy na ziemi, bowiem przez nasze imiona jesteśmy już w niebie, choć pod względem ciała i trudów przebywamy na ziemi ${ }^{76}$. Fulgencjusz z Ruspe odnosi do uczniów Jezusa proroctwo Dn 12, 1 o zbawieniu całego ludu, ,który zostanie zapisany w księdze" 77 . Symbolem społeczności wybranych i zapisanych w niebie pozostaje dla Bedy Czcigodnego liczba synów Izraela, którą zliczył Dawid (1Krn 21, 1nn.). Samo liczenie, które Jahwe uznał za czyn niegodny, wyraża czysto zewnętrzną przynależność do grona wybranych. Jest ona taka, jeśli ktoś stroni od dojrzałych czynów wiary, i dlatego ze względu na brak szczerej postawy względem Boga podlega karze ${ }^{78}$. Możliwe, że Beda zapis niebiański rozumie w sensie przynależności do Kościoła. Może być ona czysto zewnętrzna, formalna, albo też duchowa, urzeczywistniająca mistyczną jedność Ciała Chrystusa.

\section{ZACHĘTA DO POKORY I RADOŚCI}

Przytoczone interpretacje dają pogląd o sensie użytej przez Jezusa metafory. Ojcowie starają się wyjaśnić, dlaczego Bóg zapisuje imiona swoich wybranych w niebie. Stawiają sobie również pytanie dotyczące kontekstu sy-

\footnotetext{
${ }^{74}$ Por. Hieronymus, Commentarii in Esaiam II 4, 2n, CCL 73, 60n.

${ }^{75}$ Por. Beda Venerabilis, In Samuelem prophetam allegorica expositio IV 25, 3, CCL 119, 232.

${ }^{76}$ Por. Augustinus, Sermo 263A, MA I 348.

${ }^{77}$ Fulgentius, De veritate praedestinationis et gratiae lib. III 6, ed. J. Fraipont, CCL 91A, Turnholti 1968, 525n, thum. własne.

${ }^{78}$ Por. Beda Venerabilis, De tabernaculo 3, ed. D. Hurst, CCL 119A, Turnholti 1969, 134.
} 
tuacyjnego. Dlaczego Chrystus właśnie wtedy powiedział te słowa? Chodzi więc nie tylko o ich obiektywny sens, ale i pedagogię. Nadzwyczajne znaki towarzyszące już pierwszej akcji misyjnej wysłańców Chrystusa mogły budzić w nich próżność oraz samozadowolenie. W wypowiedzi Jezusa Ojcowie dostrzegają pewne antidotum na takie niebezpieczeństwo.

1. Wobec pokusy próżności. Jak sądzi Augustyn, Chrystus dostrzegał w posłanych uczniach, że radowali się samą sławą $i$ wynosili się $z$ tego powodu, że było im dane wypędzać czarty. Widział, że szukali własnej chwały, dla tego powiedział powyższe słowa. Nie powinni cieszyć się z dokonanych dzieł, o ile taka radość prowadzi do pychy. Jeśli uczeń Chrystusa nie zaniedba imienia Bożego, jego imię zostanie zapisane w niebie. Nie wszyscy dobrzy chrześcijanie wyrzucają czarty. Wszystkie jednak ich imiona są zapisane w niebie ${ }^{79}$. Tak samo Chryzostom podkreśla, że Chrystus, znając ludzką skłonność do próżności, przestrzegł swoich uczniów, aby nie cieszyli się z mocy posiadanej nad złymi duchami. Czymś większym niż to, co wzbudza próżne upodobanie i samozadowolenie, jest szukać tego, co miłe Bogu i co przynosi wspólny pożytek $^{80}$. Chrystus uzdalnia ich do dojrzałej radości, by nie byli jak małe dzieci, które odrzucają rzeczy wielkie, a podziwiają małe ${ }^{81}$. Ukierunkowaniu przez Jezusa radości na rzeczy miłe Bogu, w przeciwieństwie do cudów zagrażających skromności, Orygenes nadaje bardziej uniwersalny charakter. Wskazanie swoim uczniom nadprzyrodzonych powodów radości każe zachować ostrożność wobec radości przyziemnych. I tak Orygenes uważa, że chrześcijanin nie ma powodu, by winszować cieszącemu się ,z powodów pieniężnych, z rozległych posiadłości albo z wysokiej godności świeckiej”82. Augustyn wskazuje na niebezpieczeństwo próżności kuszącej nie tylko po dokonaniu dobrych dzieł. Ona kryje się za ciekawością kuszącą niekiedy „sługi Boże” - jeszcze przed czynieniem znaków - ,aby chcieli czynić cuda, próbować, czy ich wysłucha Bóg w cudach”. Gdy dokonają cudów, kuszeni są chełpliwością czy nawet pychą. Autor, idąc za Jezusową przestrogą, każe zwrócić słuchaczom uwagę na to, co najistotniejsze: ,czy imię twoje [...] jest zapisane w niebie?" 83 . To nie brak cudów ściąga boskie „biada” na życie chrześcijanina, ale brak imienia zapisanego w boskiej księdze. Podobnie zdaniem Piotra Chryzologa Jezus w Łk 10, 20 chciał pomóc uczniom przezwyciężyć pokusę chełpliwości. Niewiele dalej każe uważać się im za sługi nieużyteczne (Łk 11, 5). W obydwu przypadkach czyni tak dla nauki pokory:

\footnotetext{
${ }^{79}$ Por. Augustinus, Enarrationes in Ps. 91, 3, CCL 39, 1281; 130, 8, CCL 40, 1904.

${ }^{80}$ Por. Joannes Chrysostomus, In Acta Apostolorum hom. 41, 3, PG 60, 292.

${ }^{81}$ Por. tenże, Ad populum Antiochenum hom. 17, 2, PG 49, 174.

${ }^{82}$ Origenes, In Epistulam Pauli ad Romanos 9, 15, PG 14, 1224, PSP 57/2, 479.

${ }^{83}$ Augustinus, In Joannis epistulam ad Parthos tractatus 2, 13, PL 35, 1996, thum. W. Kania: Św. Augustyn, Homilie na Pierwszy List św. Jana, PSP 15/2, Warszawa 1977, 408.
} 
„aby przez wyniosłość nie utracili tego, co zdobyli przez trud, aby nie przypisywali sobie tego, czego dostapili dzięki łasce Bożej"84.

Na to samo niebezpieczeństwo wskazuje Cyryl Aleksandryjski. Po wykonaniu zleconej misji uczniowie zdają się koncentrować na dokonanych cudach i nimi się cieszyć, zamiast być wdzięczni za otrzymaną misję i apostolską godność. Chrystus pragnie więc odwrócić ich uwagę od siebie samych, czynionych cudów i wzbudzanego przez to podziwu, wskazując na to, że On jest dawcą cudotwórczych zdolności. Chce już u samych początków ich apostolstwa wyplenić próżność. Jeśli mają szukać chwały, to nie przyziemnej i taniej, polegającej na ludzkim podziwie, ale chwały w niebie będącej dopiero przedmiotem nadziei ${ }^{85}$.

2. Bóg zapisuje imiona prostaczków. Synonimem postulowanej postawy skromności względem własnych dokonań jest prostota. Jeśli Chrystus rozweselił się w duchu właśnie z takiej ekonomii Boga, który najpełniej objawia siebie prostaczkom, to z pewnością prostota jest nie tylko powodem, ale i drogą do radości. Znamienne, że w Ewangelii Łukaszowej owo rozradowanie się w duchu Jezusa następuje bezpośrednio po tym, jak pouczył uczniów, z czego mają się na prawdę radować (por. Łk 10, 21). Prostotę Chrystus przepisuje jako lekarstwo na chełpliwość. Augustyn, dostrzegając w Łk 10, 20 powyższą intencję Jezusa, by mianowicie zapobiec chełpliwości ze strony uczniów, sprawę wyjaśnia odwołując się do przypowieści o bogaczu i Łazarzu (Łk 16, 19-30). Podkreśla, że Bóg przemilczał imię bogatego, a tymczasem nazwał po imieniu ubogiego. Bóg nie zapisuje w niebie imienia bogacza, ale zapisuje imiona ubogich ${ }^{86}$. Ubogim jest człowiek, który przypisuje to, co ma, nie sobie, ale Bogu. Według Bedy Czcigodnego, właśnie wypowiedź Jezusa w Łk 10, 20 sprowokowała uczonego w Prawie do pytania o to, jak ma osiagnać życie wieczne (por. Łk 10, 25). W słowach Jezusa, który nie sprecyzował dokładnie tego, co czyni godnym nieba, znalazł powód do wystawienia Jezusa na próbę. Przez staranie, by pochwycić Jezusa na słowie, mimowolnie przyznał rację Jezusowi, który wysławiał Ojca za to, że zakrył prawdę przed mędrcami tego świata, a objawił prostaczkom (por. Łk 10, 21) ${ }^{87}$. Zapisane w niebie imiona uczniów są obrazem zbawienia ludzi o pokornym nastawieniu, którzy uczynione dobro przypisują Bogu, a nie sobie. Uczony w Prawie łudził się tymczasem, że może takie dobro czynić sam z siebie.

3. Od radości indywidualnej do społecznej. Pisarze wczesnochrześcijańscy nie poświęcają wiele miejsca nadprzyrodzonej radości, do której Jezus zachęca powracających z pierwszej wyprawy swoich uczniów. W zasadzie

\footnotetext{
${ }^{84}$ Petrus Chrysologus, Sermo 161, 6, CCL 24B, 998, tłum. własne.

${ }^{85}$ Por. Cyrillus Alexandrinus, Commentarii in Lucam 64, ed. Smith, s. 30.

${ }^{86}$ Por. Augustinus, Sermo 33A, 4, ed. C. Lambot, CCL 41, Turnholti 1961, 421.

${ }^{87}$ Por. Beda Venerabilis, In Lucae evangelium expositio III 10, 20, CCL 120, 219.
} 
można znaleźć jedynie jedną myśl św. Augustyna, która skupia się na samym wątku radości. Myśl tę podejmują późniejsi naśladowcy Augustyna. Zdaniem biskupa Hippony społeczny charakter dobra przynoszonego innym za ich sprawą, z którego mają się cieszyć, powinien kształtować w nich społeczną radość. Zostaje odrzucona radość indywidualistyczna, która każe cieszyć się z indywidualnych powodów w sposób indywidualny. Posłańcy Chrystusa mają cieszyć się nie z własnego dobra, ale dobra zbawienia wszystkich - również tych, którymi może byli skłonni gardzić ${ }^{88}$. Myśl Augustyna, również w nawiązaniu do Łk 10, 20, podejmuje Grzegorz Wielki:

„Uczmy się obfitować, abyśmy wszystko, co od Niego otrzymaliśmy, dzielili z potrzebującymi. A obfitość niech nie wynosi umysłu, aby nie cieszył się przypadkiem z tego, że ma dla siebie to, czego brakuje drugiemu, i nie cieszy się już wspólnym dobrem, ale swoim własnym"89.

Dalej Grzegorz stwierdza, że ten, kto by obfitował tylko dla siebie, przez swoją zasobność staje się gorszy, a nie lepszy, a jego radość jest egoistyczna.

Zdolność do dzielenia się z innymi dobrami przyrodzonymi i nadprzyrodzonymi idzie w parze ze zdolnością do społecznego radowania się. W innym miejscu papież, duchowy uczeń Augustyna z Hippony, przestrzega z kolei innego Augustyna, z Canterbury, dawnego współbrata w klasztorze, aby nie popadł w próżną chwałę wobec spektakularnych sukcesów misyjnych w Anglii. Zgodnie z Łk 10, 20 mają misjonarze przechodzić od radości indywidualnej i osobistej do wspólnej, od doczesnej do wiecznej. Jezus upomniał uczniów, bo ciesząc się z cudów oddawali się

„osobistej i doczesnej radości. Bo nie wszyscy wybrani czynią cuda, a jednak imiona wszystkich zapisane są w niebie. Uczniowie Prawdy powinni bowiem cieszyć się tylko z tego dobra, które mają wspólnie ze wszystkimi i w którym nie ma końca radości" $"$.

Opisując dzieje chrystianizacji Anglii, Beda Czcigodny nie omieszkał wspomnieć o tym właśnie napomnieniu Grzegorza I oraz przytoczyć powyższe słowa. Mnich angielski podkreśla tam, że papież, na wieść o sukcesach misyjnych i znakach dokonywanych przez Augustyna w Anglii, wysłał do niego list z zachętą do praktykowania radości i bojaźni Bożej - radości:

„dusze Anglów przez zewnętrzne cuda są pociaggane do wewnętrznej ła-

${ }^{88}$ Por. Augustinus, Enarrationes in PS. 130, 8, CCL 40, 1904.

${ }^{89}$ Por. Gregorius Magnus, In Hiezechielem prophetam hom. II 7, 17, ed. M. Adriaen, CCL 142, Turnholti 1971, 330, tłum. własne.

${ }^{90}$ Tenże, Epistula XI 36, ed. V. Recchia: Gregorio Magno, Opere, t. 5/4, Roma 1999, 112, thum. J. Czuj: Św. Grzegorz, Listy, IV, Warszawa 1955, 93. 
ski; bojaźni, aby pośród dziejących się znaków, słaby duch nie wyniósł się w mniemaniu o sobie" ${ }^{91}$.

Tak oto nie ma już miejsca na samozadowolenie i indywidualizm. Radość godna ucznia Chrystusa dotyczy dóbr, które są wspólne i wieczne.

4. Radość z dobra wlasnego i innych. Dla równowagi dodajmy, że radość ze zbawienia innych nie stoi w sprzeczności z radością z własnego zbawienia. Pseudo-Klemens podkreśla, że ten, kto czyni różne znaki, na przykład wypędza demony, czyni to dla dobra innych. Nie należy jednak poprzestawać na radości z pożytku innych. Tymczasem potrzeba zadbać o własne dobro i nim się cieszyć ${ }^{92}$. Jeśli w powyższych wypowiedziach postuluje się radość społeczną, akcentując dobro innych, to z pewnością wskazuje się na pewien jej aspekt, gdyż w prawdziwej radości społecznej jest miejsce zarówno na radość z własnego dobra, jak i dobra innych.

Jak widzimy, patrystyczna egzegeza Łk 10, 20 stanowi bogatą refleksję nad kilkoma wątkami teologicznymi. Po pierwsze, wskazuje na pierwszeństwo wiary, miłości i innych cnót oraz dzieł chrześcijańskich przed charyzmatem wypędzania złych duchów, a w dalszym planie - na pierwszeństwo duchowej postawy chrześcijanina przed jego zewnętrznym zaangażowaniem. Pod tym względem wypowiedzi Ojców są dobrym komentarzem do innych słów Jezusa: „Lekarzu, ulecz samego siebie” (Łk 4, 23). Następnie, egzegeza ta czyni obraz zapisu w niebie punktem wyjścia do refleksji nad ludzkim przeznaczeniem i wolnością. W niej echem odbija się jedna z ważniejszych dyskusji teologicznych w starożytności nad relacją między przeznaczeniem człowieka do zbawienia a jego wolnością. Dalej, Ojcowie podejmuja próbę ścisłej egzegezy Jezusowej obietnicy w Łk 10, 20. Taka ich refleksja jest dość oszczędna, ale świadczy o szczerym intelektualnym wysiłku, aby odnaleźć istotny sens słów Jezusa o zapisie w niebie imion Jego wybranych. Najkrócej mówiąc, Ojcowie dostrzegają w tym obrazie zapowiedź wybrania, powołania i zbawienia tych, których Bóg chce. W końcu, w swojej hermeneutyce nasi autorzy uwzględniają cel pedagogiczny słów Jezusa. Jest nim wychowanie uczniów do pokory i dojrzałej radości. W kilku podstawowych wątkach Ojcowie zdają się nawiązywać do egzegezy Orygenesa. Ten niewielki fragment patrystycznej interpretacji Ewangelii potwierdza, jak bardzo Aleksandryjczyk zaważył na myśli swoich następców.

${ }^{91}$ Beda Venerabilis, Historia ecclesiastica gentis Anglorum I 31, 2, ed. A. Crépin et alii, SCh 489, Paris 2005, 252.

${ }^{92}$ Por. Ps-Clemens Romanus, Homiliae 9, 22, GCS 42, 140. 
Sama radość nie stoi w centrum egzegezy Ojców tekstu Łk 10, 20. Fakt ten zdaje się oddawać wewnętrzną logikę słów Ewangelii. Tam również głównym przedmiotem nie jest radość, ale powód do niej. Być może mieści się w tym pewna pedagogia. Radość staje się w jakimś sensie mimowolnym skutkiem pewnego stanu. Sama radość jest łatwiejsza niż długa droga, która do niej prowadzi. Więcej refleksji wymagają właśnie warunki, które trzeba spełnić, aby móc się radować. Zachęta do radości bez uwzględnienia takiej jej specyfiki stawałaby się pustym słowem.

\section{THE JOY OF THE DISCIPLES OF JESUS (LUC 10: 20) IN THE PATRISTIC INTERPRETATION}

\section{(Summary)}

In this article the author presents patristic interpretation of Luc 10: 20 about the joy of Christ's disciples, whose names are written in the heaven. The author portrayed the thought both of Latin, as well as Greek authors, dating back until the exegesis of the Bede the Venerable. The thought of Fathers is concentrated on such aspects as: 1. priorities of the internal attitude, especially of the faith and love, before making miracles; 2. metaphors of ,the Book of the Living" and of „the Book of the Just”; 3. theological meaning of Jesus' promise; 4. parenetic aspect, and in this case - encouragement to the humility and joy. 